\title{
PMA synergistically enhances apicularen A-induced cytotoxicity by disrupting microtubule networks in HeLa cells
}

Kang-Sik Seo ${ }^{1}$, Jong-Seok Kim¹, Ji-Hoon Park ${ }^{1}$, Kyoung-Sub Song ${ }^{1}$, Eun-Jin Yun ${ }^{1}$, Jong-Il Park ${ }^{1}$ Gi Ryang Kweon ${ }^{1,3}$, Wan-Hee Yoon ${ }^{1}$ Kyu Lim ${ }^{1,2,3^{*}}$ and Byung-Doo Hwang ${ }^{1 *}$

\begin{abstract}
Background: Combination therapy is key to improving cancer treatment efficacy. Phorbol 12-myristate 13-acetate (PMA), a well-known PKC activator, increases the cytotoxicity of several anticancer drugs. Apicularen A induces cytotoxicity in tumor cells through disrupting microtubule networks by tubulin down-regulation. In this study, we examined whether PMA increases apicularen A-induced cytotoxicity in HeLa cells.

Methods: Cell viability was examined by thiazolyl blue tetrazolium (MTT) assays. To investigate apoptotic potential of apicularen A, DNA fragmentation assays were performed followed by extracting genomic DNA, and caspase-3 activity assays were performed by fluorescence assays using fluorogenic substrate. The cell cycle distribution induced by combination with PMA and apicularen A was examined by flow cytometry after staining with propidium iodide (PI). The expression levels of target proteins were measured by Western blotting analysis using specific antibodies, and a-tubulin mRNA levels were assessed by reverse transcription polymerase chain reaction (RT-PCR). To examine the effect of combination of PMA and apicularen A on the microtubule architecture, $a$-tubulin protein and nuclei were visualized by immunofluorescence staining using an anti-a-tubulin antibody and $\mathrm{Pl}$, respectively.
\end{abstract}

Results: We found that apicularen A induced caspase-dependent apoptosis in HeLa cells. PMA synergistically increased cytotoxicity and apoptotic sub- $G_{1}$ population induced by apicularen $A$. These effects were completely blocked by the PKC inhibitors Ro31-8220 and Go6983, while caspase inhibition by Z-VAD-fmk did not prevent cytotoxicity. RNA interference using siRNA against PKCa, but not PKC $\beta$ and PKC $\gamma$, inhibited cytotoxicity induced by combination PMA and apicularen A. PMA increased the apicularen A-induced disruption of microtubule networks by further decreasing a- and $\beta$-tubulin protein levels in a PKC-dependent manner.

Conclusions: These results suggest that the synergy between PMA and apicularen A is involved by PKCa activation and microtubule disruption, and that may inform the development of novel approaches to treat cancer.

Keywords: PMA, Apicularen A, PKCa, Cell death, Microtubule disruption

\section{Background}

Apicularen A is a potent cytotoxic macrolide isolated from the myxobacterial genus Chondromyces [1] that induces apoptosis in several cancer cell lines such as the murine RAW 264.7 leukemia macrophage line and the human HL-60 promyelocytic leukemia cell line [2-4]. In

\footnotetext{
*Correspondence: kyulim@cnu.ac.kr; bdhwang@cnu.ac.kr

'Department of Biochemistry, College of Medicine, Chungnam National University, Daejeon, Korea

${ }^{2}$ Cancer Research Institute, Chungnam National University, Daejeon, Korea Full list of author information is available at the end of the article
}

addition, apicularen A induces apoptotic cell death in human HM7 colon cancer cells by up-regulating Fas ligand and disrupting microtubule architecture [5].

Protein kinase $\mathrm{C}(\mathrm{PKC})$ is a serine/threonine protein kinase family; PKC family members are classified into three major groups based on their activation pathways [6]: classical PKC isotypes $(\alpha, \beta \mathrm{I}, \beta \mathrm{II}$ and $\gamma)$ are activated by diacylglycerol (DAG) and calcium, novel PKC isotypes $(\delta, \varepsilon$, $\eta$ and $\theta$ ) are activated by DAG, and atypical PKC isotypes $(\zeta$ and $\mathrm{t} / \lambda)$ are not regulated by DAG or calcium [7]. PKCs are associated with the regulation of cellular processes

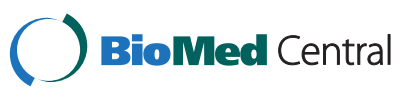

(c) 2014 Seo et al.; licensee BioMed Central Ltd. This is an open access article distributed under the terms of the Creative Commons Attribution License (http://creativecommons.org/licenses/by/2.0), which permits unrestricted use, distribution, and reproduction in any medium, provided the original work is properly cited. 
such as cell proliferation, differentiation and cell death [7]; however, the role of each PKC isotype in cellular processes, especially cell death, is controversial. For example, PKC $\delta$ and PKC $\theta$ are involved in apoptotic cell death through caspase-3-mediated proteolytic activation $[8,9]$, while PKC $\varepsilon$ and PKC $\zeta$ are involved in cell survival $[10,11]$. In addition, PKC activators such as phorbol 12-myristate 13-acetate (PMA) or bryostatin 1 can increase or decrease anticancer drug activity depending on the drugs and cell lines tested [12-16]. Thus, the functional significance of PKCs in cell death mechanisms remains elusive.

Microtubules are an important cytoskeletal component formed by the polymerization of $\alpha$ - and $\beta$-tubulin heterodimers [17]; they regulate several cellular processes including the maintenance of cell shape, motility, transport, organelle distribution and chromosome segregation during mitosis [18]. Since cancer cells proliferate more rapidly than normal cells, microtubules are considered a suitable therapeutic target and several anticancer drugs inhibit their function [19]. For example, Vinca alkaloids inhibit tumor cell proliferation by inducing the depolymerizaiton of microtubules [20], and taxanes induce apoptosis by promoting microtubule assembly [21]. Apicularen A disrupts microtubule networks by inhibiting tubulin synthesis [5]. Efforts to develop more effective cancer therapy combinations with microtubule-interfering agents are underway. The finding that PMA increases the antitumor activity of paclitaxel, a chemotherapeutic agent that inhibits tubulin polymerization, in vitro and in a xenograft model of prostate cancer [22] prompted us to test whether PMA increases apicularen A-induced cell death. The results of the present study demonstrate that PMA-mediated PKC $\alpha$ activation strongly increases apicularen A-induced apoptotic cell death and disruption of microtubule networks in HeLa cells.

\section{Methods}

\section{Cell culture}

Human HeLa cervical cancer cells (ATCC, Rockville, MD) were cultured in Dulbecco's modified Eagle's medium supplemented with $10 \%$ fetal bovine serum and antibiotics. Cells were maintained at $37^{\circ} \mathrm{C}, 5 \% \mathrm{CO}_{2}$ and $95 \%$ air.

\section{Antibodies and chemicals}

Apicularen A was provided by Dr. Ahn (Division of Ocean Science, Korea Maritime University, Busan, Korea) and dissolved in dimethyl sulfoxide. Phorbol 12-myristate 13acetate (PMA), thiazolyl blue tetrazolium bromide (MTT), anti- $\alpha$-tubulin and anti- $\beta$-tubulin antibodies were purchased from Sigma (St Louis, MO, USA). Anti-PARP and anti-actin antibodies were purchased from Santa Cruz Biotechnology (Santa Cruz, CA, USA). Anti-caspase-3 antibody was purchased from R\&D Systems (Wiesbaden, Germany). Z-VAD-fmk, Ro31-8220 and Go6983 were purchased from Calbiochem (San Diego, CA, USA). All other reagents were molecular biology grade.

\section{Cell viability assay}

Cell viability was assessed by thiazolyl blue tetrazolium (MTT) assay. Exponentially growing cells were exposed to apicularen $\mathrm{A}$ in the presence or absence of PMA for 24 and 48 hours. MTT solution was added to each well $(0.5 \mathrm{mg} / \mathrm{ml})$ and incubated for 2 hours. Cell viability was assessed by measuring the absorbance at $570 \mathrm{~nm}$ in an ELISA plate reader.

\section{DNA fragmentation assay}

The cells were lysed using buffer containing $300 \mathrm{mM}$ Tris$\mathrm{HCl}$ (pH 7.5), $100 \mathrm{mM} \mathrm{NaCl}, 10 \mathrm{mM}$ EDTA, $200 \mathrm{mM}$ sucrose and $0.5 \%$ SDS. Intracellular DNA was extracted with phenol/chloroform (1:1) and chloroform/isoamylalcohol (24:1). DNA was precipitated and digested in $10 \mathrm{mM}$ Tris- $\mathrm{HCl}$ (pH 8.0), $1 \mathrm{mM}$ EDTA and $40 \mu \mathrm{g} / \mathrm{ml}$ RNase A for 1 hour at $37^{\circ} \mathrm{C}$. Then, DNA $(10 \mu \mathrm{g})$ was resolved by electrophoresis in a $1.2 \%$ agarose gel supplemented with ethidium bromide $(0.2 \mu \mathrm{g} / \mathrm{ml})$, and DNA fragmentation was examined by ultraviolet transillumination.

\section{Caspase-3 activity assay}

Cell extracts were prepared by suspending $2 \times 10^{6} \mathrm{HeLa}$ cells in $100 \mu \mathrm{L}$ TTE buffer [10 mM Tris-HCl (pH 8.0), $0.5 \%$ Triton X-100, $10 \mathrm{mM}$ EDTA] on ice for $30 \mathrm{~min}$, and then centrifuging at $15,000 \times g$ for 10 minutes at $4^{\circ} \mathrm{C}$. Lysates $(30 \mu \mathrm{g}$ total protein in $10 \mu \mathrm{l})$ were mixed with $90 \mu \mathrm{l}$ assay buffer [20 mM HEPES (pH 7.5), 10\% glycerol, $2 \mathrm{mM}$ DTT] containing $40 \mu \mathrm{M}$ Ac-DEVD-AFC. Caspase-3 activity was measured at $37^{\circ} \mathrm{C}$ using a spectrofluorometric plate reader (Perkin-Elmer LS-50B., Foster City, CA, USA) in kinetic mode using excitation and emission wavelengths of $400 \mathrm{~nm}$ and $505 \mathrm{~nm}$.

\section{Western blotting analysis}

HeLa cells were lysed in buffer containing $50 \mathrm{mM}$ Tris$\mathrm{HCl}$ (pH 7.5), $150 \mathrm{mM} \mathrm{NaCl}, 1 \%$ nonidet P-40, 0.5\% deoxycholate, $0.1 \%$ SDS and protease inhibitor cocktail (Roche Applied Science, Mannheim, Germany). Cell lysates were subjected to SDS-PAGE and transferred onto nitrocellulose (Pall Life Sciences, Port Washington, NY, USA) or PVDF membranes (Millipore, Woburn, MA, USA). The membranes were first probed with primary antibodies and then with HRP-conjugated secondary antibodies (Calbiochem), and the proteins were detected using the ECL system (Amersham Biosciences Corp., Piscataway, NJ, USA).

\section{Cell cycle analysis}

HeLa cells exposed to apicularen A in the presence or absence of PMA were washed with phosphate buffered 
saline (PBS) and fixed in $70 \%$ ethanol at $-20^{\circ} \mathrm{C}$ overnight. Before analysis, cells were centrifuged and incubated with propidium iodide $(50 \mu \mathrm{g} / \mathrm{ml})$ supplemented with RNase A $(1 \mathrm{mg} / \mathrm{ml})$ for 30 minutes at room temperature. The relative DNA content was measured by flow cytometry using a Becton-Dickinson FACSort and by manual gating using CellQuest software.

\section{Reverse transcription-polymerase chain reaction (RT-PCR)}

The mRNA level of $\alpha$-tubulin was measured by RT-PCR. Total RNA was isolated using the TRIzol ${ }^{\circ}$ reagent (Invitrogen, Karlsruhe, Germany) according to the manufacturer's instructions. Complementary DNA (cDNA) was synthesized using AMV reverse transcriptase at $42^{\circ} \mathrm{C}$ for 1 hour. The mixture was then boiled for 5 minutes to inactivate reverse transcriptase and quickly chilled on ice. The cDNAs were amplified by RT-PCR using the HiPi Plus PCR master mix (Elpis Biotech, Korea). PCR products were separated on $1.2 \%$ agarose gels with ethidium bromide $(0.2 \mu \mathrm{g} / \mathrm{mL})$, and amplification products were examined by ultraviolet transillumination.

\section{Immunofluorescence assay}

HeLa cells were seeded onto glass coverslips and were exposed to apicularen $\mathrm{A}$ in the presence or absence of PMA. The cells were washed twice with PBS, permeabilized with $0.25 \%$ triton $\mathrm{X}-100$ and $0.5 \%$ glutaraldehyde for 1 minute at room temperature, and then fixed with $1 \%$ glutaraldehyde for 10 minutes before overnight incubation with anti- $\alpha$-tubulin antibody diluted 1:500. After washing three times in PBS containing 0.1\% Tween20 (PBS/T), cells were incubated for 1 hour with secondary antibody (Alexa Fluor 488 goat anti-mouse IgG diluted 1:400) in the dark. After washing five times, cells were stained with $20 \mu \mathrm{g} / \mathrm{ml}$ propidium iodide and $1 \mathrm{mg} / \mathrm{ml}$ RNase A for 20 minutes at room temperature. Microtubules and nuclei were observed using an FV-500 fluorescence microscope (Olympus, Dulles, VA, USA). The fluorescence intensity was quantified using image $J$ software.

\section{Statistical analysis}

Results are expressed as the means \pm SE. Statistical significance was assessed using the Student's $t$-test and analysis of variance (ANOVA). $P<0.05$ was considered to be significant. The combined effect of PMA and apicularen $\mathrm{A}$ (combination index) was calculated using the formula $\% \mathrm{AB} / \% \mathrm{~A} \times \% \mathrm{~B}$, where $\mathrm{A}$ and $\mathrm{B}$ are the effects of each individual agent and $A B$ is the effect of the combination. When the ratio (combination index) is 1 the effect is considered additive; when the combination index is significantly greater than or less than 1 , the effect is considered subadditive (negative synergism) or supraadditive (positive synergism), respectively [23]. Statistical significance value of the combination index was compared with the additive combination index of 1 by one-sided Student's t-test.

\section{Results}

\section{Apicularen A induces cytotoxicity in HeLa cells}

The effect of apicularen A on HeLa cell growth was performed. Apicularen A decreased cell viability in a concentration and time-dependent manner (Figure 1A). In addition, suspended HeLa cells exposed to apicularen A exhibited membrane blebbing, nuclear condensation and shrinkage of the cytoplasm (Figure 1B). To investigate whether these morphological changes were caused by apoptosis, genomic DNA was purified and analyzed for fragmentation. As shown in Figure $1 \mathrm{C}$, apicularen A induced DNA fragmentation at 48 hours. Since caspase- 3 plays a crucial role in apoptotic cell death by cleaving poly (ADP-ribose) polymerase (PARP) to suppress the DNA repair pathway [24], we tested the potential involvement of caspase- 3 in apicularen A-induced cell death by measuring caspase- 3 activity and the PARP cleavage. HeLa cells exposed to apicularen A exhibited a 3 -fold increase in caspase- 3 activity compared to control cells (Figure 1D). In addition, apicularen A increased the active form of caspase- 3 and the cleaved form of PARP (Figure 1E). Taken together, these results indicate that apicularen A induces apoptotic cell death in HeLa cells.

\section{PMA increases apicularen A-induced cytotoxicity in HeLa cells}

The role of PKC in the mechanism of action of antitumor agents is controversial since PKC synergizes with some agents and antagonizes others [12,14,15,25,26]. PMA was used to assess the effect of PKC on apicularen A-induced cytotoxicity. PMA has a similar chemical structure to DAG and activates PKCs by interacting with the DAG binding site [27]. HeLa cells were exposed to $100 \mathrm{nM}$ apicularen A and 20 nM PMA; as shown in Figure 2A and Table 1, PMA synergistically increased the cytotoxicity of apicularen $\mathrm{A}$ in a time-dependent manner. This finding was supported by time-lapse video microscopy, showing that combination of PMA and apicularen A strongly induced cell death to a greater extent than apicularen A alone (Additional file 1: Movie S1). Next, flow cytometry was used to assess the potential effect of PMA on the cell cycle. Forty percent of apicularen A-treated cells were apoptotic (sub-G $G_{1}$ peak) at 48 hours, while no apoptosis was detected in control or PMA-treated cells (Figure 2B). In addition, $80 \%$ of the cells exposed to the combination of apicularen A and PMA were apoptotic at 48 hours, indicating that PMA increased apicularen A-induced apoptotic cell death. Since apicularen A induced apoptotic cell death through caspase activation (Figure 1E), we investigated whether the cytotoxicity induced by the combination of PMA and apicularen A also depended on caspase 

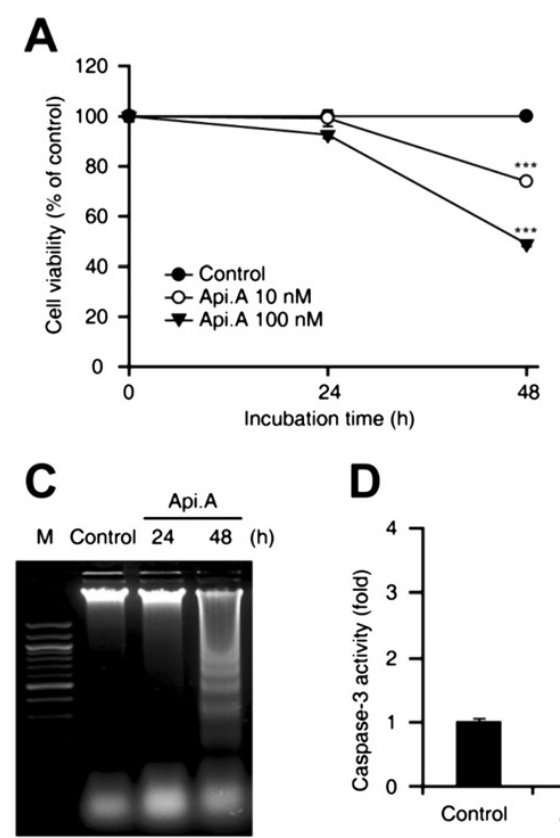

D

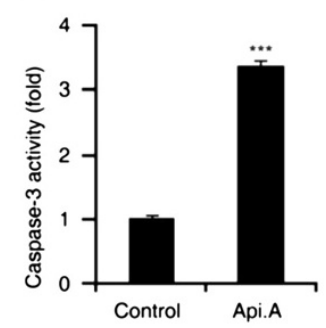

B

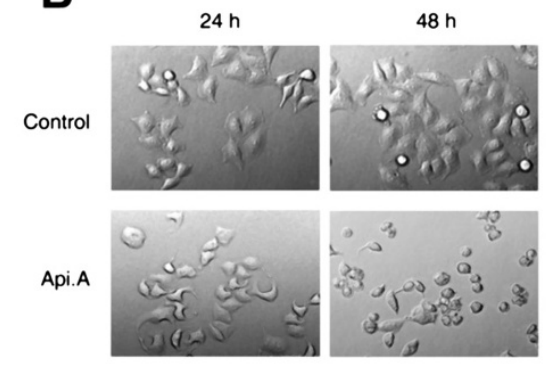

E

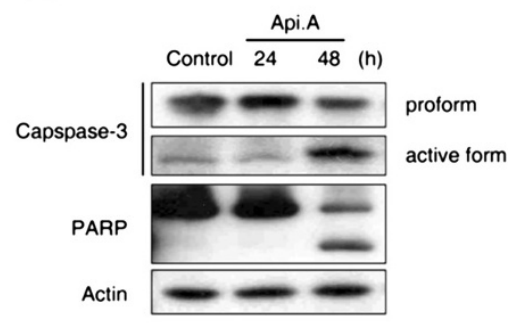

Figure 1 Apicularen A induces apoptotic cell death in HeLa cells. A. HeLa cells were exposed to 10 or $100 \mathrm{nM}$ apicularen A. Cell viability was analyzed by MTT assay. B. HeLa cells were exposed to $100 \mathrm{nM}$ apicularen A for 24 and 48 hours. Phase contrast images (X200) were acquired using an inverted microscope. C. Total genomic DNA of apicularen A-treated HeLa cells was extracted and analyzed by agarose gel electrophoresis. D. Caspase-3 activity of apicularen A-treated HeLa cells was assessed at 48 hours using the caspase-3 fluorogenic peptide substrate DEVD-AFC. E. HeLa cells were exposed to $100 \mathrm{nM}$ apicularen A. Cell lysates were subjected to Western blotting with anti-caspase-3 and anti-PARP antibodies. All error bars indicate \pm SEM. ${ }^{* * *} P<0.001$.

activation. The pan-caspase inhibitor Z-VAD-fmk did not block the cytotoxicity induced by the drug combination (Figure 2C), indicating that the synergy is caspase-independent. Since PMA is involved in several PKC-independent cellular processes associated with cell proliferation and differentiation [28-30], the role of PKC activation on the synergy with apicularen A was tested by exposing cells to PKC inhibitor Ro31-8220 before adding PMA and apicularen A. Ro31-8220 showed no cytotoxicity in HeLa cells at 48 hours, and pretreatment with Ro31-8220 completely blocked the synergistic apoptotic activity of PMA and apicularen A (Figure 2D and 2E). The PKC inhibitor Go6983 also suppressed the effect of PMA on apicularen A-induced cytotoxicity (Figure 2F). These results suggest that PKC activation increases apicularen A-induced apoptotic cell death.

\section{PKCa mediates the effect of PMA on apicularen A-induced cytotoxicity}

To identify which PKC isotype is involved in the increase in apicularen A-induced cell death observed in the presence of PMA, cells were pretreated with siRNAs specific for individual PKCs and exposed to PMA and apicularen A. Since PMA activates the classical and novel PKC isotypes and Go6983 inhibits PKC $\alpha, \beta, \delta, \gamma$ and $\zeta[27,31]$, specific siRNAs against PKC $\alpha, \beta$ and $\gamma$ were needed; the isotype-specificity of the knockdown was confirmed by transient transfection and Western blotting in HeLa cells (Figure 3A). As shown in Figure 3B, knockdown of $\mathrm{PKC} \alpha$, but not that $\mathrm{PKC} \beta$ or $\mathrm{PKC} \gamma$, significantly decreased the apoptosis induced by the combination of PMA and apicularen A. These results demonstrate that PKC $\alpha$ mediates the synergistic effect of PMA on apicularen A-induced cell death in HeLa cells.

\section{PMA increases apicularen A-mediated tubulin down-regulation}

We previously reported that the mechanism of apicularen A-induced apoptotic cell death in human HM7 colon cancer cells partially involved a decrease in intracellular tubulin levels [5]. Thus, we investigated whether PMA increases apicularen A-induced apoptotic cell death by further down-regulating tubulin. Apicularen A decreased total $\alpha$-tubulin protein levels in a time-dependent manner (Figure 4A). At 48 hours, the combination of PMA and apicularen A decreased $\alpha$-tubulin protein levels to a greater extent than apicularen A alone, while PMA alone had no effect. Similar results were obtained for $\beta$-tubulin (Figure 4B). Since apicularen A down-regulates tubulin levels by decreasing tubulin mRNA levels in HM7 cells [5], tubulin mRNA levels were assessed by RT-PCR in cells exposed to PMA and apicularen A. PMA did not affect $\alpha$-tubulin mRNA levels in apicularen A-treated cells (Figure 4C). Microtubule architecture was assessed by 


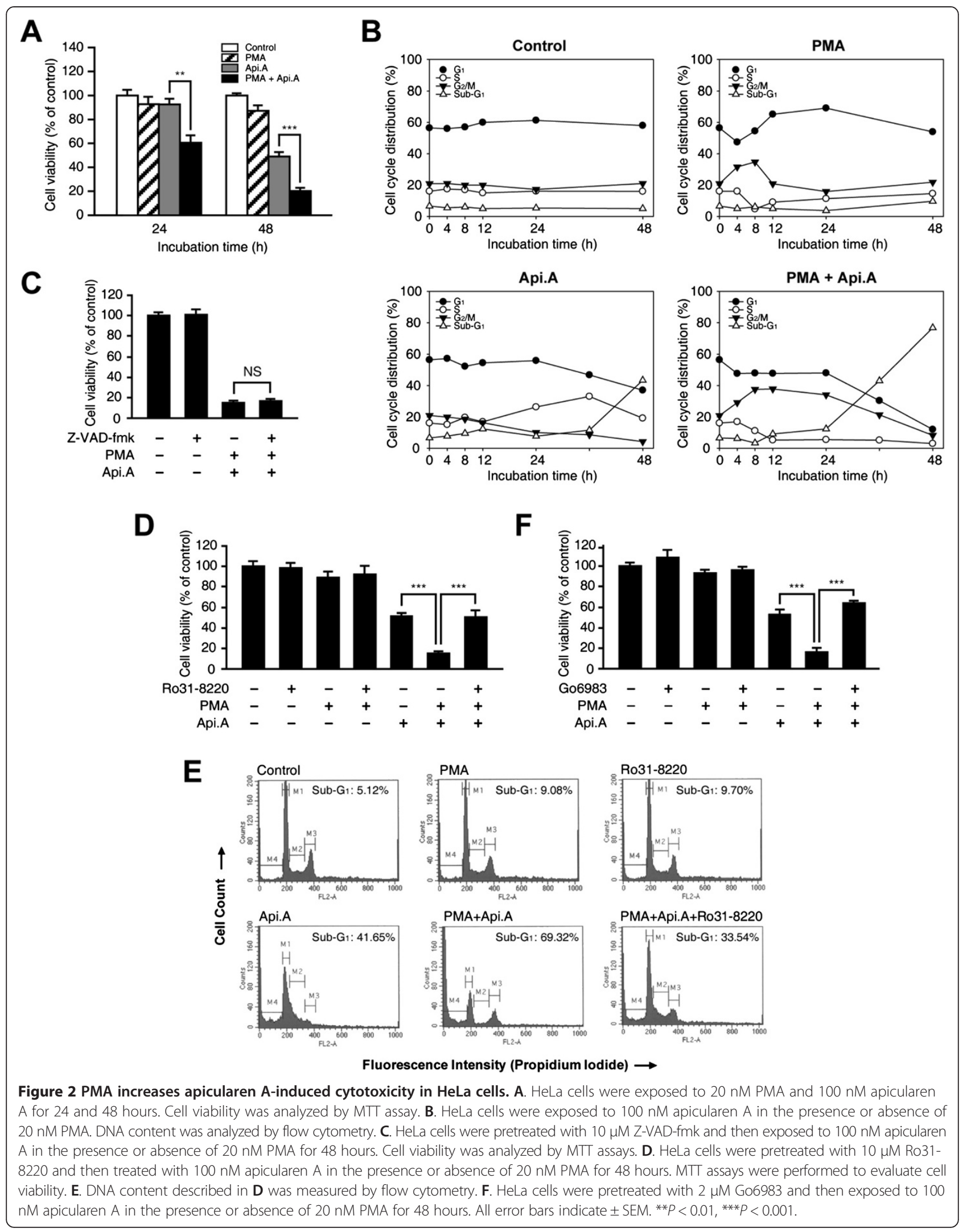


Table 1 Analysis of the interaction between the inhibitory effect of PMA in combination with apicularen $A$ on the viability of HeLa cells

\begin{tabular}{ccc}
\hline Combination index & p value & Interaction \\
\hline $0.113 \pm 0.004$ & 0.001 & Synergy
\end{tabular}

The combination index was calculated using the formula $\% \mathrm{AB} / \% \mathrm{~A} \times \% \mathrm{~B}$, as described under "Methods". The value indicate \pm SEM.

immunofluorescence using anti- $\alpha$-tubulin antibody and propidium iodide (PI). PMA-treated cells exhibited similar microtubule architecture to control cells. By contrast, apicularen A induced irregular microtubule networks and nuclear localization, and reduced $\alpha$-tubulin protein levels. In addition, PMA further increased the effect of apicularen $\mathrm{A}$ on the microtubule networks and on $\alpha$-tubulin levels (Figure 4D). Given that PMA increases apicularen A-induced cell death by increasing PKC activity, the

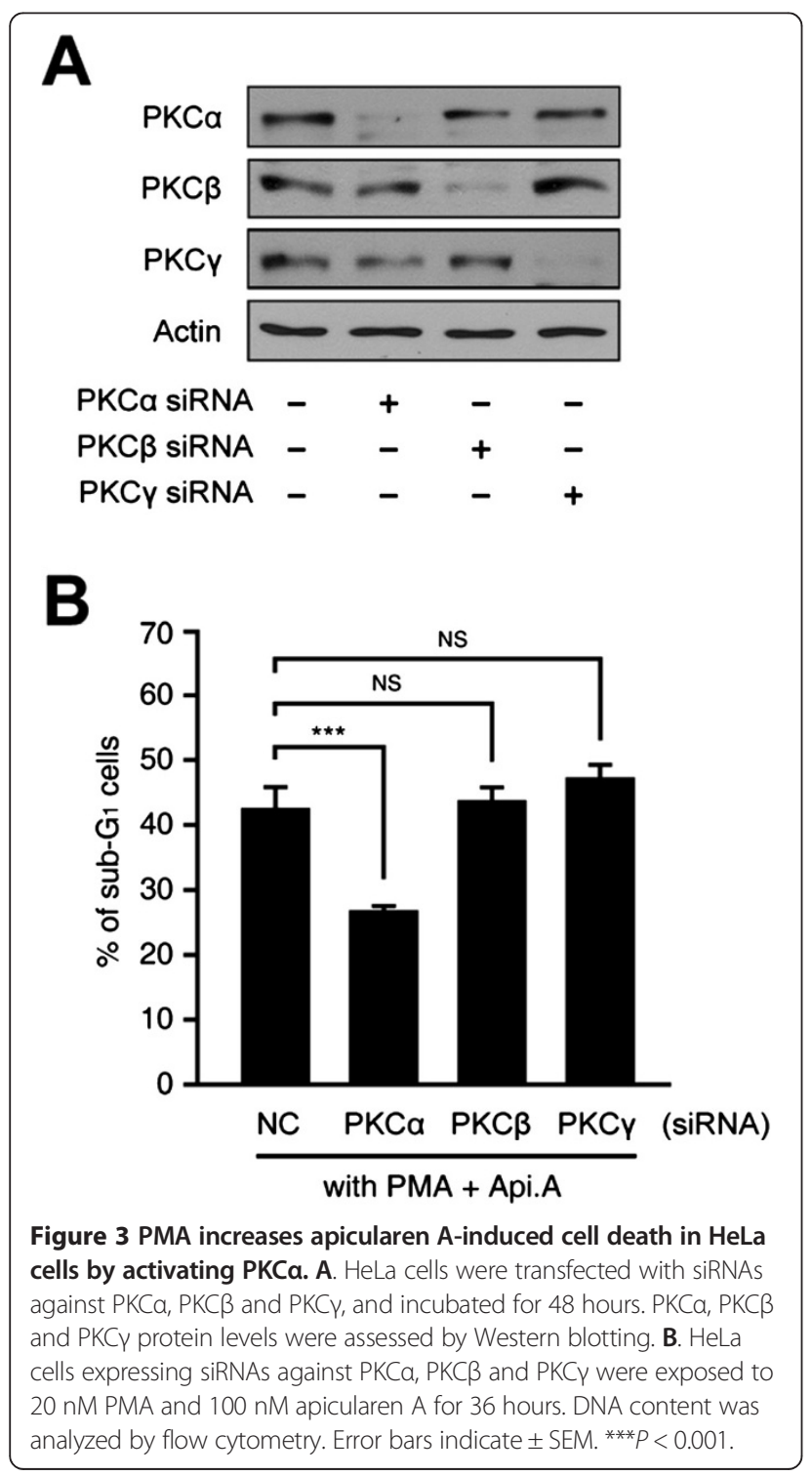

possibility that PKC activation might also be responsible for the effect of PMA and apicularen A on tubulin protein levels was considered. HeLa cells were pretreated with Ro31-8220 and then exposed to apicularen A in the presence or absence of PMA. As expected, inhibition of PKC activity by Ro31-8220 partially restored tubulin levels (Figure 4E). Taken together, these results suggest that the potentiation of apicularen A-induced apoptotic cell death by PMA is associated with decreased tubulin protein levels.

\section{Discussion}

The present study shows that PMA increases the cytotoxicity of apicularen A in HeLa cells. PKC inhibition completely blocked the synergistic effect of PMA on apicularen A-induced cytotoxicity and tubulin downregulation. Specific knockdown of PKC isotypes revealed that $\mathrm{PKC} \alpha$ is the unique mediator of that effect among PKC family members.

PMA induces apoptotic cell death in several kinds of cells $[32,33]$. In addition, the combination of PMA and anticancer drugs increases cytotoxicity [12,34], suggesting that PMA may be suitable as an anticancer agent within a drug combination regimen. In this study, although PMA alone did not induce cell death, it increased the cell death induced by apicularen A synergistically. This effect was completely blocked by the PKC inhibitor Ro318220, indicating that PKC is involved in the synergistic mechanism. Among PKC isotypes, PKC $\delta$ mainly promotes apoptosis [35]; however, since Ro31-8220 does not inhibit PKC [36], we had to consider that other PKC isotype(s) may be involved in the synergy. Specific knockdown of individual PKC isotypes demonstrated that $\mathrm{PKC} \alpha$ is the mediator of the PMA-stimulated increase in apicularen Ainduced apoptotic cell death in HeLa cells. Whether PKC $\alpha$ also mediates the synergistic effect of PMA with other anticancer drugs requires further investigation.

PMA is known to induce $G_{2} / M$ phase arrest in several cell lines [37,38], and PKC $\alpha$ activation is involved in the accumulation of cells in $\mathrm{G}_{2} / \mathrm{M}$ phase [38]. Our results show that the combination of PMA and apicularen A arrests cells in the $G_{2} / M$ phase, whereas exposure of cells to PMA alone only transiently increases the number of cells in the $G_{2} / M$ phase. The number of cells arrested in the $\mathrm{G}_{2} / \mathrm{M}$ phase in the presence of both PMA and apicularen A decreases in a time-dependent manner and leads to an increase in the number of cells in the sub-G1 phase. These results are consistent with previous findings showing that prolonged arrest in $G_{2} / M$ phase causes apoptotic cell death by blocking cell cycle progression [39].

We previously reported that apicularen A decreases tubulin protein levels and disrupts microtubule networks in human HM7 colon cancer cells by decreasing tubulin mRNA levels [5]. The present study reveals that apicularen A also promotes the disruption of microtubule networks 


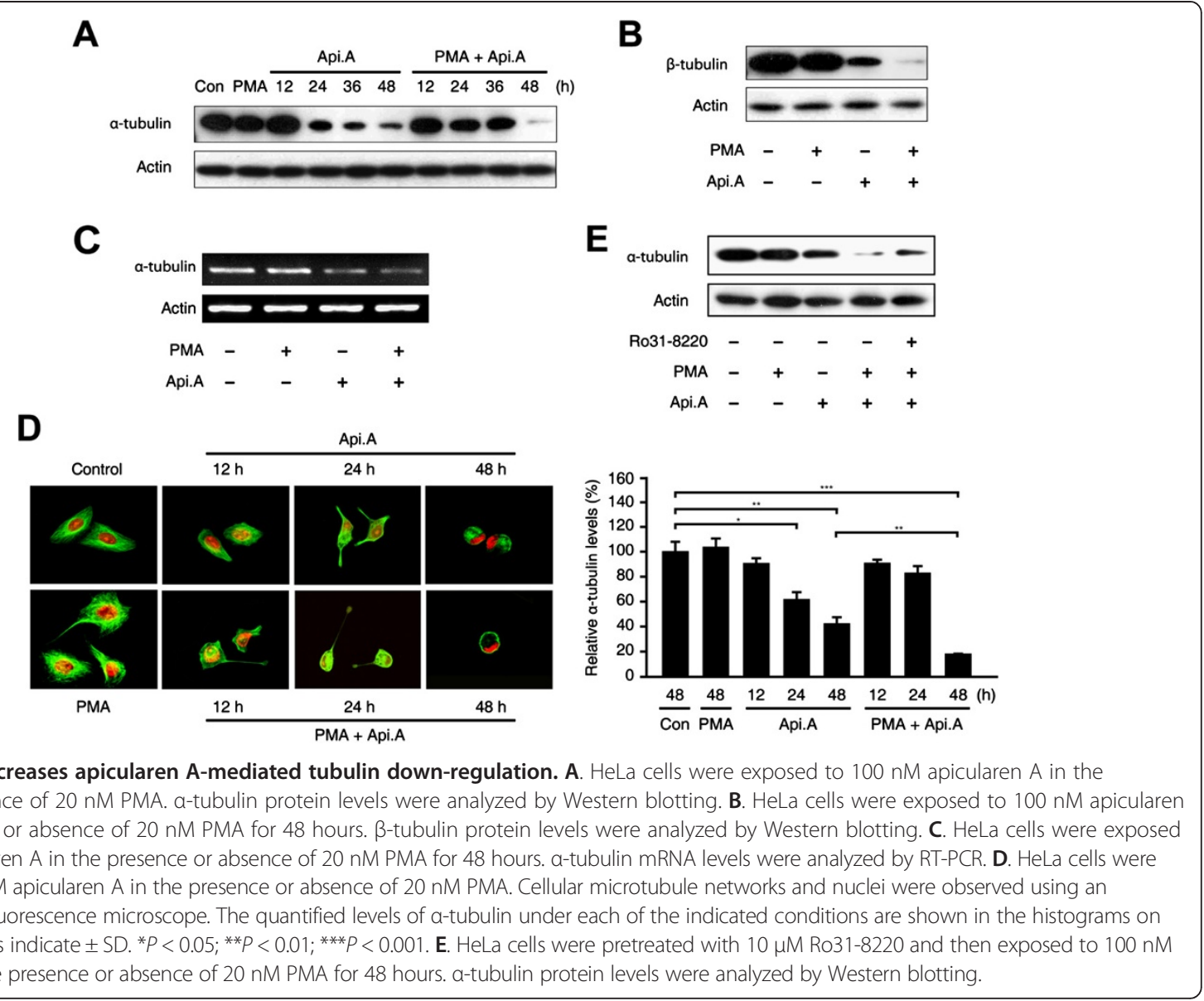

through down-regulation of tubulin protein expression in HeLa cells, and that this phenomenon increased by PMA; however, PMA did not affect tubulin mRNA levels in the presence of apicularen A. The tubulin protein levels of cells exposed to the combination of PMA and apicularen A decreased slowly for 36 hours, and were decreased severely at the final time point ( 48 hours). Since a critical concentration of soluble tubulin is required for conservation of polymerized tubulin [40], and since PMA induces tubulin polymerization by regulating microtubule kinetics [41], it is possible that the microtubule polymerization induced by PMA may be initially resistant to apicularen Ainduced tubulin down-regulation but finally collapses when soluble tubulin levels fall below the critical threshold required to support the polymerized networks. Since a decrease in tubulin protein levels and suppression of tubulin polymerization inhibit cell survival $[42,43]$, lower tubulin protein levels in cells exposed to both PMA and apicularen A may explain the increased cytotoxicity observed in the presence of the two drugs. By contrast, since interference with microtubule dynamics decreases cell migration [44], the migration of cells exposed to the combination of PMA and apicularen A is expected to be lower than that of control cells; however, PMA regulates actin cytoskeleton reorganization and induces cell migration [45]. In addition, the combination of PMA and apicularen A did not change actin protein levels. Thus, we speculate that, although the combination of PMA and apicularen A induces $G_{2} / M$ phase arrest by disrupting microtubule networks, increased actin reorganization may contribute to increased cell migration (Additional file 1: Movie S1).

\section{Conclusions}

In summary, this study shows that the combination of PMA and apicularen A synergistically induces apoptotic cell death in HeLa cells by mediating PKC $\alpha$ activation and disrupting intracellular microtubule networks. Since combination therapy is key to improving cancer treatment efficacy, these results may guide the development of novel therapeutic approaches to cancer.

\section{Additional file}

Additional file 1: Movie S1. HeLa cells were exposed to 20 nM PMA in the presence or absence of $100 \mathrm{nM}$ apicularen A for 48 hours. Time-dependent cell morphology was visualized using time-lapse video microscopy; control (upper left), PMA (upper right), apicularen A (lower right), combination of PMA and apicularen A (lower left). One second in the movie $=1$ hour 18 minutes in real time. 


\section{Competing interests}

The authors declare that they have no competing interests.

\section{Authors' contributions}

KS Seo, JS Kim, JH Park, KS Song, and EJ Yun carried out the molecular studies and performed statistical analysis. YH Jung, J Park, GR Kweon, and $\mathrm{WH}$ Yoon assisted in the interpretation of results. KS Seo, K Lim, and BD Hwang drafted and completed the manuscript. All authors read and approved the final manuscript.

\section{Acknowledgments}

This study was supported by a National Research Foundation of Korea (NRF) grant funded by the Korean government (MEST) (2007-0054932).

\section{Author details}

${ }^{1}$ Department of Biochemistry, College of Medicine, Chungnam National University, Daejeon, Korea. ${ }^{2}$ Cancer Research Institute, Chungnam National University, Daejeon, Korea. ${ }^{3}$ Infection Signaling Network Research Center, Chungnam National University, Daejeon, Korea.

Received: 2 April 2013 Accepted: 15 January 2014

Published: 22 January 2014

\section{References}

1. Kunze B, Jansen R, Sasse F, Hofle G, Reichenbach H: Apicularens A and B, new cytostatic macrolides from Chondromyces species (myxobacteria): production, physico-chemical and biological properties. $J$ Antibiot (Tokyo) 1998, 51(12):1075-1080.

2. Hong J, Yamaki K, Ishihara K, Ahn JW, Zee O, Ohuchi K: Induction of apoptosis of RAW 264.7 cells by the cytostatic macrolide apicularen A. J Pharm Pharmacol 2003, 55(9):1299-1306.

3. Hong J, Ishihara K, Zee O, Ohuchi K: Induction of apoptosis by apicularen A in human promyelocytic leukemia cell line HL-60. Planta Med 2005, 71(4):306-312

4. Hong J, Yokomakura A, Nakano Y, Ban HS, Ishihara K, Ahn JW, Zee O, Ohuchi K: Induction of nitric oxide production by the cytostatic macrolide apicularen $\mathrm{A}$ [2,4-heptadienamide, $\mathrm{N}-[(1 \mathrm{E})-3-[(3 \mathrm{~S}, 5 \mathrm{R}, 7 \mathrm{R}, 9 \mathrm{~S})$ 3,4,5,6,7,8,9,10-octahydro-7,14 dihydroxy-1-oxo-5,9-epoxy-1H-2-benzoxacyclododecin-3-yl]-1 propenyl]-, (2Z,4Z)-(9CI)] and possible role of nitric oxide in apicularen A-induced apoptosis in RAW 264.7 cells. J Pharmacol Exp Ther 2005, 312(3):968-977.

5. Kim JS, Lee YC, Nam HT, Li G, Yun EJ, Song KS, Seo KS, Park JH, Ahn JW, Zee $O$, et al: Apicularen $A$ induces cell death through Fas ligand upregulation and microtubule disruption by tubulin down-regulation in HM7 human colon cancer cells. Clin Cancer Res 2007, 13(21):6509-6517.

6. Koivunen J, Aaltonen V, Peltonen J: Protein kinase C (PKC) family in cancer progression. Cancer Lett 2006, 235(1):1-10.

7. Spitaler M, Cantrell DA: Protein kinase $C$ and beyond. Nat Immunol 2004 5(8):785-790.

8. Emoto $Y$, Manome $Y$, Meinhardt G, Kisaki H, Kharbanda S, Robertson M, Ghayur T, Wong WW, Kamen R, Weichselbaum R, et al: Proteolytic activation of protein kinase $C$ delta by an ICE-like protease in apoptotic cells. EMBO J 1995, 14(24):6148-6156.

9. Datta R, Kojima H, Yoshida K, Kufe D: Caspase-3-mediated cleavage of protein kinase $C$ theta in induction of apoptosis. J Biol Chem 1997, 272(33):20317-20320.

10. Basu A, Lu D, Sun B, Moor AN, Akkaraju GR, Huang J: Proteolytic activation of protein kinase $C$-epsilon by caspase-mediated processing and transduction of antiapoptotic signals. J Biol Chem 2002, 277(44):41850-41856.

11. Smith L, Chen L, Reyland ME, DeVries TA, Talanian RV, Omura S, Smith JB: Activation of atypical protein kinase $C$ zeta by caspase processing and degradation by the ubiquitin-proteasome system. J Biol Chem 2000, 275(51):40620-40627.

12. Rahmani M, Dai Y, Grant S: The histone deacetylase inhibitor sodium butyrate interacts synergistically with phorbol myristate acetate (PMA) to induce mitochondrial damage and apoptosis in human myeloid leukemia cells through a tumor necrosis factor-alpha-mediated process. Exp Cell Res 2002, 277(1):31-47.

13. Mohanty S, Huang J, Basu A: Enhancement of cisplatin sensitivity of cisplatin-resistant human cervical carcinoma cells by bryostatin 1 . Clin Cancer Res 2005, 11(18):6730-6737.
14. Wang $S$, Wang $Z$, Dent $P$, Grant $S$ : Induction of tumor necrosis factor by bryostatin 1 is involved in synergistic interactions with paclitaxel in human myeloid leukemia cells. Blood 2003, 101(9):3648-3657.

15. Harper N, Hughes MA, Farrow SN, Cohen GM, MacFarlane M: Protein kinase $\mathrm{C}$ modulates tumor necrosis factor-related apoptosis-inducing ligandinduced apoptosis by targeting the apical events of death receptor signaling. J Biol Chem 2003, 278(45):44338-44347.

16. Meng XW, Heldebrant MP, Kaufmann SH: Phorbol 12-myristate 13-acetate inhibits death receptor-mediated apoptosis in Jurkat cells by disrupting recruitment of Fas-associated polypeptide with death domain. J Biol Chem 2002, 277(5):3776-3783.

17. Westermann $\mathrm{S}$, Weber K: Post-translational modifications regulate microtubule function. Nat Rev Mol Cell Biol 2003, 4(12):938-947.

18. Hadfield JA, Ducki S, Hirst N, McGown AT: Tubulin and microtubules as targets for anticancer drugs. Prog Cell Cycle Res 2003, 5:309-325.

19. Aneja R, Zhou J, Vangapandu SN, Zhou B, Chandra R, Joshi HC: Drugresistant T-lymphoid tumors undergo apoptosis selectively in response to an antimicrotubule agent, EM011. Blood 2006, 107(6):2486-2492.

20. Ngan VK, Bellman K, Hill BT, Wilson L, Jordan MA: Mechanism of mitotic block and inhibition of cell proliferation by the semisynthetic Vinca alkaloids vinorelbine and its newer derivative vinflunine. Mol Pharmacol 2001, 60(1):225-232.

21. Park SJ, Wu CH, Gordon JD, Zhong X, Emami A, Safa AR: Taxol induces caspase-10-dependent apoptosis. J Biol Chem 2004, 279(49):51057-51067.

22. Zheng $X$, Chang RL, Cui XX, Avila GE, Hebbar V, Garzotto M, Shih WJ, Lin Y, Lu SE, Rabson AB, et al: Effects of 12-O-tetradecanoylphorbol-13-acetate (TPA) in combination with paclitaxel (Taxol) on prostate Cancer LNCaP cells cultured in vitro or grown as xenograft tumors in immunodeficient mice. Clin Cancer Res 2006, 12(11 Pt 1):3444-3451.

23. Calviello G, Di Nicuolo F, Serini S, Piccioni E, Boninsegna A, Maggiano N, Ranelletti FO, Palozza P: Docosahexaenoic acid enhances the susceptibility of human colorectal cancer cells to 5-fluorouracil. Cancer Chemother Pharmacol 2005, 55(1):12-20.

24. Sliskovic I, Mutus B: Reversible inhibition of caspase-3 activity by iron(III): potential role in physiological control of apoptosis. FEBS Lett 2006 580(9):2233-2237.

25. Gomez-Angelats M, Bortner CD, Cidlowski JA: Protein kinase C (PKC) inhibits fas receptor-induced apoptosis through modulation of the loss of $\mathrm{K}+$ and cell shrinkage. A role for PKC upstream of caspases. J Biol Chem 2000, 275(26):19609-19619.

26. Gomez-Angelats $M$, Cidlowski JA: Protein kinase $C$ regulates FADD recruitment and death-inducing signaling complex formation in Fas/ CD95-induced apoptosis. J Biol Chem 2001, 276(48):44944-44952.

27. Simpson PC: Beta-protein kinase $C$ and hypertrophic signaling in human heart failure. Circulation 1999, 99(3):334-337.

28. Suga S, Wu J, Ogawa Y, Takeo T, Kanno T, Wakui M: Phorbol ester impairs electrical excitation of rat pancreatic beta-cells through PKCindependent activation of KATP channels. BMC Pharmacol 2001, 1:3.

29. Stan RV, Tkachenko E, Niesman IR: PV1 is a key structural component for the formation of the stomatal and fenestral diaphragms. Mol Biol Cell 2004, 15(8):3615-3630.

30. Malakooti J, Sandoval R, Amin MR, Clark J, Dudeja PK, Ramaswamy K: Transcriptional stimulation of the human NHE3 promoter activity by PMA: PKC independence and involvement of the transcription factor EGR-1. Biochem J 2006, 396(2):327-336.

31. Phan D, Stratton MS, Huynh QK, McKinsey TA: A novel protein kinase C target site in protein kinase $D$ is phosphorylated in response to signals for cardiac hypertrophy. Biochem Biophys Res Commun 2011, 411(2):335-341.

32. Gonzalez-Guerrico AM, Kazanietz MG: Phorbol ester-induced apoptosis in prostate cancer cells via autocrine activation of the extrinsic apoptotic cascade: a key role for protein kinase C delta. J Biol Chem 2005, 280(47):38982-38991.

33. Lai JM, Lu CY, Yang-Yen HF, Chang ZF: Lysophosphatidic acid promotes phorbol-ester-induced apoptosis in TF-1 cells by interfering with adhesion. Biochem J 2001, 359(Pt 1):227-233.

34. Zheng X, Chang RL, Cui XX, Avila GE, Lee S, Lu YP, Lou YR, Shih WJ, Lin Y,

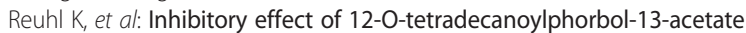
alone or in combination with all-trans-retinoic acid on the growth of LNCaP prostate tumors in immunodeficient mice. Cancer Res 2004, 64(5):1811-1820. 
35. Reyland ME: Protein kinase Cdelta and apoptosis. Biochem Soc Trans 2007, 35(Pt 5):1001-1004.

36. Brenner W, Beitz S, Schneider E, Benzing F, Unger RE, Roos FC, Thuroff JW, Hampel C: Adhesion of renal carcinoma cells to endothelial cells depends on PKCmu. BMC Cancer 2010, 10:183.

37. Arita Y, Buffolino P, Coppock DL: Regulation of the cell cycle at the G2/M boundary in metastatic melanoma cells by 12-0-tetradecanoyl phorbol13-acetate (TPA) by blocking p34cdc2 kinase activity. Exp Cell Res 1998, 242(2):381-390.

38. Oliva JL, Caino MC, Senderowicz AM, Kazanietz MG: S-Phase-specific activation of PKC alpha induces senescence in non-small cell lung cancer cells. J Biol Chem 2008, 283(9):5466-5476.

39. Mollinedo F, Gajate C: Microtubules, microtubule-interfering agents and apoptosis. Apoptosis 2003, 8(5):413-450.

40. Jordan MA, Kamath K, Manna T, Okouneva T, Miller HP, Davis C, Littlefield $B A$, Wilson L: The primary antimitotic mechanism of action of the synthetic halichondrin E7389 is suppression of microtubule growth Mol Cancer Ther 2005, 4(7):1086-1095.

41. Robinson JM, Vandre DD: Stimulus-dependent alterations in macrophage microtubules: increased tubulin polymerization and detyrosination. I Cell Sci 1995, 108(Pt 2):645-655.

42. Barlow SB, Gonzalez-Garay ML, Cabral F: Paclitaxel-dependent mutants have severely reduced microtubule assembly and reduced tubulin synthesis. J Cell Sci 2002, 115(Pt 17):3469-3478.

43. Banan A, Smith GS, Rieckenberg CL, Kokoska ER, Miller TA: Protection against ethanol injury by prostaglandin in a human intestinal cell line: role of microtubules. Am J Physiol 1998, 274(1 Pt 1):G111-G121.

44. Siegrist SE, Doe CQ: Microtubule-induced cortical cell polarity. Genes Dev 2007, 21(5):483-496.

45. Sumagin $R$, Robin $A Z$, Nusrat $A$, Parkos $C A$ : Activation of PKCbetall by PMA facilitates enhanced epithelial wound repair through increased cell spreading and migration. PLOS One 2013, 8(2):e55775.

doi:10.1186/1471-2407-14-36

Cite this article as: Seo et al.: PMA synergistically enhances apicularen A-induced cytotoxicity by disrupting microtubule networks in HeLa cells. BMC Cancer 2014 14:36.

\section{Submit your next manuscript to BioMed Central and take full advantage of:}

- Convenient online submission

- Thorough peer review

- No space constraints or color figure charges

- Immediate publication on acceptance

- Inclusion in PubMed, CAS, Scopus and Google Scholar

- Research which is freely available for redistribution 